AperTO - Archivio Istituzionale Open Access dell'Università di Torino

Work-related stress among correctional officers: A qualitative study

This is a pre print version of the following article:

Original Citation:

Availability:

This version is available http://hdl.handle.net/2318/1598195

since 2016-10-05T12:03:07Z

Published version:

DOI:10.3233/WOR-152238

Terms of use:

Open Access

Anyone can freely access the full text of works made available as "Open Access". Works made available under a Creative Commons license can be used according to the terms and conditions of said license. Use of all other works requires consent of the right holder (author or publisher) if not exempted from copyright protection by the applicable law. 


\title{
Work-related stress among correctional officers: A qualitative study
}

\author{
Sara Viotti* \\ Dipartimento di Psicologia, Universitá degli Studi di Torino, Torino, Italy
}

Received 10 October 2014

Accepted 1 June 2015

\begin{abstract}
.
BACKGROUND: Correctional officers (COs) are exposed to various factors likely to jeopardize their health and safety. Even if numerous studies have been focused on work-related stress among COs, few studies have been carried out in Italy.

OBJECTIVE: Indentify the work-related factors and comprehend how they negatively affect the COs' psychological health in the Italian penal system.

METHODS: A qualitative approach was employed. Twenty-eight COs employed in a detention block of an Italian jail were interviewed face-to-face. For the analyses of the text, Template Analysis technique was followed.

RESULTS: The analyses of the text highlighted six macro-categories and thirteen categories hierarchically linked to them: A) Intrinsic work-related factors with six categories: demanding contact with prisoners, high level of responsibility, health risks, critical events, lack of intellectual and social stimulation, and conflict value; B) Factors related to the type of contract and work organization: challenging working hours contrasted with social time, and relocation; C) Social factors: relationships with colleagues and hierarchy; D) Organizational factors: organizational injustice, E) External factors: negative social image; F) Physical environmental factors: physical structure of the prison building.

CONCLUSIONS: The results indicated that COs are at high risk of stress. More specifically, the analyses highlighted that the most stressful part of the COs' job concerns their relationship with the inmates.
\end{abstract}

Keywords: Occupational risk factors, occupational health, jail, template analysis, italy

\section{Background}

In Italy, correctional officers (COs) belong to a "military" and "civil jurisdiction" corps which is part of the Italian State Police force. They are mostly employed in prisons, in the security departments, where they carry out duties that ensure the implementation of the measures which deprive the inmates of their freedom and ensure order and security within the prison and its various blocks. The Italian law n. 395 enacted in 1990 also established that, in addition to the above-mentioned

*Address for correspondence: Sara Viotti Dipartimento di Psicologia, Universitá degli Studi di Torino, Via Verdi 8, 10124, Torino, Italy. Tel.: +39011 6702044; E-mails: sara.viotti@gmail.com; sviotti@unito.it. duties related to security, COs should participate in the observation and rehabilitation of detainees by working in multidisciplinary teams which include psychological and educational personnel (e.g., psychologists, educators, etc.).

The literature, which was mainly developed in North America, highlights that COs are likely to develop high levels of stress and disorders. In particular, there are a large numbers of studies that have documented that these workers are prone to low levels of satisfaction, well-being and commitment toward the job and organization, and high levels of burnout [1-10]. Some studies have shown that the COs are also exposed to the risk of being affected by post-traumatic stress disorder, especially in view of the frequency with which they find 
themselves having to deal with critical events such as being assaulted by a prisoner or a prisoner suicide [11]. COs tend to report worse health conditions than the general public. For example, in the study by Ghaddar et al. [12], carried out in a Spanish prison, the COs reported a low level of work ability and expected that this would worsen with age. In the study by Morse et al. [13], carried out in the USA, $72.8 \%$ of respondents reported symptoms of high blood pressure and consumption of larger quantities of alcohol and cigarettes than the national average. In the study by Obidoa and colleagues [14], about a third of the respondents reported symptoms of depression. Finally, from a study carried out by Stack and Tsoudis [15], it was observed that the risk of suicide among prison guards was 39\% higher than that of the rest of the population of working age.

The literature has also highlighted numerous factors responsible for negative effect on the health and wellbeing of this occupational category. In agreement with the main models proposed in the occupational health psychology field [16-18], it is possible to group these factors into five main categories: work content factors, factors related to the type of contract and work schedule, social factors, organizational factors, and external factors.

Work content factors. In this context, the literature has highlighted a number of aspects that are liable to adversely affect the psychological health of COs.

The factor that has probably drawn most attention is the role conflict. In the literature, it is considered to be one of the main causes of stress among COs [19-21]. In fact, numerous studies have pointed out that COs carry out daily duties which are potentially in conflict with one another such as maintaining security and discipline as well as dealing with the rehabilitation and reintegration of the prisoners [22, 23].

The dangers related to the physical health of COs also cause stress [24, 25] since COs are often victims of physical abuse. In a study carried out in a French jail by Boudoukha et al. [26], over $87 \%$ of COs had experienced either verbal, physical, or armed assualt. From the same study, it was observed that COs who had been subjected to physical or armed assualt had higher burnout levels than prison guards who had not experienced physical abuse.

Another equally important issue concerns the relationship between COs and prisoners. Working in direct contact with people detained against their will is very difficult and requires considerable energy at emotional, cognitive, and physical levels [16]. These problematic relationships with inmates was seldom studied [23, 27].
The studies carried out indicated that the more time COs spent with inmates, the more burnout symptoms they reported. Some scholars have pointed out that the relationship between "jailers" and "prisoners" is characterized by continuous conflict. For example, studies conducted in the psycho-sociological field [28] have shown that a vicious cycle can arise in the prisonerguard relationship when aggressiveness by the prisoner causes strong psychological tension in the $\mathrm{CO}$, which can lead to punitive and impulsive actions, which consequently boosts the prisoner's aggression.

There are other aspects related to the job that have been found to negatively affect the health of COs, especially regarding stress and burnout. Among those most studied are: the lack of autonomy, high responsibility, work overload, monotony, and the underutilization of skills $[3,6,7,39]$.

Factors related to the type of contract and work schedule. Two main aspects could be included in this category. The first is inadequate pay. For example, a study by Castle and Martin [30] found that COs satisfaction with annual pay was significantly negatively associated with job stress.

The other is night shift schedule. As several studies have highlighted, night shift interferes with COs' family lives, and, as a consequences, could contribute to increased levels of fatigue and stress among COs [31, 32].

Social factors. In prison, the assignement of duties is strongly focused on the individual rather than the group. Consequently, group identity and solidarity among COs are weakly developed since they interact only occasionally [16]. In fact, several studies have shown that the lack of social support perceived by COs is related to the high level of burnout which is especially due to the sense of loneliness and abandonment typical in their line of work [17].

Another critical aspect is the COs' relationship with immediate superiors. A study carried out on Italian COs found that this is the main cause of stress [33]. Lack of support and unfair reprimands are particularly associated with high levels of emotional exhaustion and deterioration of health [34].

Other elements of risk are incidents of harassment, bullying, and other forms of psychological violence that are common occurrences in prisons according to the literature [35-37].

External factors. In this context, poor social status is the most reported factor in the literature. The profession of $\mathrm{CO}$ is not considered to be particularly prestigious from an intellectual and social point of view [16], and 
their reputation is damaged even more by the emphasis given to episodes of violence towards prisoners by $\mathrm{COs}$ reported by the media $[17,33]$.

Organizational factors. The impact of organizational structure on COs psychological health has been extensively studied by Lambert et al. [38-41].

According to these studies, the lack of justice is the most important predictor, within the organizational factors, of negative consequences on COs' psychological health. Other studies $[18,42,43]$ have found that both procedural (i.e., the perception of fairness of the processes and procedures used to arrive at organizational outcomes) and distributive (i.e., the perception of fairness in distribution and allocation of outcomes within an organization based on inputs by employees) justice have a strong association with stress.

Lambert showed also that lack of integration (i.e., the extent that an organization allows different work groups to work together in cooperation and coordination to accomplish the major tasks and goals of the organization) as well as of instrumental communication (i.e. the extent that an organization allows and stresses that different work groups work in cooperation and coordination to accomplish the major tasks and goals of the organization) contribute to decrease job satisfaction and commitment and to increase stress and turnover intention [38, 39].

According to the recent meta-analysis conducted by Finney et al. [18], also unclear goals and policies, lack of decision making ability, and of support from the organization have a role in affecting COs' psychological health. Moreover, Finney et al. [10] concluded that these factors show more consistent associations than task-level factors (e.g., work overload, skill utilization) with COs' job stress and burnout.

Even if numerous international studies have been focused on the topic of the work-related stress of COs, few studies have been carried out in Italy in the last decade [33, 44].

There is considerable evidence regarding the seriousness of the situation in which Italian COs find themselves that is not generally found in the literature. For example, the number of suicides is definitely the most significant. According to Prati and Boldrin [33], on average $10 \mathrm{COs}$ per year have committed suicide since 2000 out of a total workforce of about 45,000 . This is a staggering figure when compared with the national suicide rate which, according to ISTAT $^{1}$, is approxi-

\footnotetext{
${ }^{1}$ National Institute of Statistics. To retrieve the web page that report statistics on suicide: http://www.istat.it/it/archivio/suicidi
}

mately 6 suicides per 100,000 annually. According to these estimates, the number of suicides among COs is almost three times the national average.

Given the shortage of studies referring to the Italian context in the literature, studies of a qualitative nature are required, which would allow an evaluation of the health issues suffered by this professional group, which has not been thus far acknowledged.

In light of these observations, the aim of the present study, carried out in an Italian prison with a qualitative approach, is to identify the psychosocial risk factors among COs and to comprehend how they negatively affect theirs psychological health.

\section{Materials and methods}

\subsection{Context of the study, data collection and participants:}

The study was carried out in a male detention block of a large prison situated in a North-Western Italian region. At the time of the study (November $2010-$ June 2011), there were approximately 60 correctional officers working in the block that houses approximately 200 prisoners divided into 8 sections characterized by different security levels: high, medium and low.

Through a formal process - which involved the assessment of the aims and procedures of the study from an ethical point of view by the Regional Department of Prison Administration and the prison management the researcher obtained the permits required to enter the detention block, to take a recording device, and to interview the correctional officers during working hours. One of the superintendents working in the block was assigned the task of assisting the researcher to select COs for the study by the prison director. Specifically, the superintendent was in charge of asking COs to meet with the researcher and to schedule their interviews, bearing in mind the daily duties to be carried out in the blocks and sections. Twenty-eight correctional officers agreed to participate in the interview ${ }^{2}$.

\footnotetext{
${ }^{2}$ The research and its aim was presented by the researcher to the COs during the monthly detention block meeting to which she was invited. For the data collection, the Administration established that, in order not to interfere with the regular job activities, the interviews would be carried out only one day per week and during the hours between 9:00 a.m. and 12:30 p.m. and between 1:00 p.m. and 3:30 p.m. For this reason and because of the unpredictability of the COs working time, the times and the days in which the interviews would carried out were planned in advance before collecting the permission from
} 
The researcher explained the purpose of the study to each of the COs, asked them for permission to audio record the interview, and guaranteed anonymity when processing personal data before proceeding with the interview. The interviews took place face-to-face with an average duration of 48 minutes. The shortest interview lasted 27 minutes while the longest lasted 65 minutes.

\subsection{The check-list for the data collection \& the data analyses}

The check-list for the interview and the data analyses were developed following the Template Analyses method proposed by King [45-47]. According to King, Template Analysis can be described as a technique for thematically organizing and analyzing textual data. The essence of Template Analysis is that the researcher produces a list of codes, i.e., the "template", representing themes identified in textual data. The template is organized in a way that represents the relationships between themes, as defined by the researcher, most commonly involving a hierarchical structure.

Template Analysis is a flexible technique since it may used for studies that adopt a deductive as well as an inductive approach. It is also indicated for mixed approaches. Indeed, according to King, some "a priori" themes can be indentified in advance, that may be modified and added to during the interpretation process of the data.

In the present study, a mixed design was employed that involves simultaneously a deductive and an inductive approach.

A initial template including very broad "a priori" themes was developed and used as a guide to build the check-list for conducting the semi-structured interviews. Specifically, based on the analysis carried out on the literature reported in the introduction, an initial template was built, including five main categories (first-order themes): work content factors, factors related to the type of contract and work organization, social factors, organizational factors, and external factors. The semi-structured interviews were carried out

the COs. On the morning of the planned day, the superintendent, after consulting the schedules of the day, identified the sections (typically no more than two sections and 2-4 COs per day), in which, in his opinion, it would be acceptable to temporarily dismiss the workers. After the count of the inmates (about 7:30 a.m.), he would ask the COs on duty, personally, their availability for attending the interview. Globally, in that way, 36 workers were reached, and 28 of them agreed to participate in the research. starting with some broad stimulus questions for all participants ${ }^{3}$ : "Do you think that your work is stressful?" and "If yes, in your opinion, what are the elements that make your work stressful?"; "What are your feelings and emotions concerning the situations to which you are exposed?"

After such general questions, more specific questions aimed at investigating the five areas identified from the literature were asked. Examples of questions are: "Are there any (other) aspects of the content of your job that you think are stressful?"; "Are there any (others) aspects related to your contract situation that negatively affect you well-being at work?"; "How do you describe the social climate here among the staff of the detention block? In this context, are there any aspect that negatively affect your daily work experience?"; "How do you describe the way in which this institution as a whole works? What about the detention block level? Are there any aspects at either level that negatively affect your work experience?"; "Are there any aspects, also not directly related at the workplace, that negatively affect your job experience?"

After the first five interviews was carried out, the template was modified in order to include some subcategories (second-order themes), hierarchically linked to the main five categories (first-order themes), which emerged from these first interviews (in Table 2, the subcategories identified at this step were underlined). As a consequence, also the check-list was modified in order to include questions specifically aimed at investigating whether the factor described a source stress for the interviewee.

Once all the interviews were fully transcribed, analyses was addressed at identifying sections of text that were relevant to the research's aims, and marking them with one or more appropriate codes from the initial template. Thus, every statement in the text of the interviews that described a stressor related to the work of COs was included in one of the five main categories mentioned above or placed in a specially designed macro-category. As the categories gradually took shape, other categories

\footnotetext{
${ }^{3}$ The semi-structured interviews were developed following a "funnel technique." Before introducing questions concerning the research topic properly, some question aimed at collecting the work history, a description of the job currently carried out in the interviews, as well as a description about the way in which the detention block was organized were posed. Those questions had a double function. First, they helped to "break the ice" during the interview. Second, the narrative material thus collected was useful during the data analyses, because, even thought it was only indirectly related to the aim of the research, it provided a framework, helping the researcher to read the data and to identify how to interpret it.
} 
Table 1

Demographic characteristics of study participants

\begin{tabular}{lcccc}
\hline & $n$ & $m$ (years) & sd & $\begin{array}{c}\text { min-max } \\
\text { (years) }\end{array}$ \\
\hline $\begin{array}{l}\text { Gender } \\
\quad \text { Male }\end{array}$ & 28 & & & \\
$\begin{array}{l}\text { Educational level } \\
\quad \text { Elementary school }\end{array}$ & 1 & & & \\
$\quad$ Middle school & 9 & & & \\
$\quad$ High school & 16 & & & \\
$\quad$ Bachelor/Master degree & 2 & & & \\
Age & & 36.22 & 10.23 & $23-62$ \\
Job seniority & & 12.14 & 10.40 & $1-45$ \\
\hline
\end{tabular}

in Table 2). It was then observed that it was possible to divide them into other sub-categories (third-order codes) that make it possible to examine other more specific aspects of the sources of stress reported. Below, as well as in the template in Table 2, the categories are listed in descending order according to the number of participants who made statements related to the category in question.

1) High-demanding contact with prisoners (hierarchically subordinated to A- work content factors). This aspect emerged in all 28 interviews. It was not unusual that some participants used the term "cohabitation" ["forced cohabitation" [5] $n=8$ ] when referring to the pervasive, complex, and ambivalent relationship with the inmates. In regard to this category, it was possible to outline 4 subcategories that qualify the experience of discomfort related to the work of the participants:

a) Feeling overwhelmed by prisoners' requests: this aspect emerges from the reports made by all 28 participants. According to the participants, the factors that make these requests stressful are, their frequency, the excessive number and variety: "everybody wants something fast, [...] then there are a lot of problems, there are those who do not have any clothes, others have no blankets, then those who want to talk to the prison director, another has an abscess [...] and so on. [8]" In some cases, the experience of stress occurs because of the impossibility of coping with these requests due to lack of resources, "it is true that they are detainees, there is however a limit to deprivation, in here their dignity is taken away and we are the ones who have to face the prisoners" [12] in other cases, stress occurs due to the fact that the $\mathrm{CO}$ does not consider himself to be the appropriate recipient of the request, "at times they ask us things and if we could we would try to help but we cannot do anything. [3]"

In respect to this topic, the feeling of discomfort comes from being cognitively overloaded ["one sometimes goes insane" [5]] and from feeling powerless due to the impossibility of responding to certain requests considered to be inappropriate from a formal point of view, yet legitimate on human terms: "It's very frustrating when you see that you cannot do anything to help him. [19]"

\footnotetext{
${ }^{5}$ The number in brackets indicates the interview number. The numbers accord with the order in which the interviews were conducted.
} ative social image of the profession, which proves to be the cause of considerable stress for the respondents as demonstrated in literature and the results obtained, although it is not directly related to working conditions.

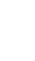


Table 2

Template

\begin{tabular}{|c|c|}
\hline$\overline{\mathrm{A}^{\dagger}}$ & $\begin{array}{l}\text { 1) High demanding contact with prisoners [28] (134)§ } \\
\text { a) Feeling overwhelmed by the prisoners' requests [28] (54) } \\
\text { b) Management of the emotional reactions and aggressive auto/hetero behavior of the prisoner/s [28] (49) } \\
\text { c) Coming into contact with the emotional suffering of the prisoner [15] (21) } \\
\text { d) Managing relationships with foreign prisoners [7] (10) }\end{array}$ \\
\hline A & $\begin{array}{l}\text { 2) High level of responsibility [28](66) } \\
\text { a) Ensuring security in an "open system" [21] (32) } \\
\text { b) "Safeguarding" the life of a prisoner [20] (34) }\end{array}$ \\
\hline $\mathrm{E}$ & $\begin{array}{l}\text { 3) Negative social image [26](54) } \\
\text { a) The "batterer" [20] (34) } \\
\text { b) The "uneducated" [9] (11) } \\
\text { c) The "conspirator" [7] (9) }\end{array}$ \\
\hline A & $\begin{array}{l}\text { 4) Health risks [24](40) } \\
\text { a) Infections and diseases [17] (26) } \\
\text { b) Accidents [10] (14) }\end{array}$ \\
\hline $\mathrm{A}$ & $\begin{array}{l}\text { 5) Critical events [18](36) } \\
\text { a) Events in which the CO's health is not at risk [9](14) } \\
\text { b) Events which present risks to the physical safety of COs [16] (22) }\end{array}$ \\
\hline $\mathrm{B}$ & $\begin{array}{l}\text { 6) Challenging working hours contrasting with social time [17](39) } \\
\text { a) Working during the holidays [16] (19) } \\
\text { b) Working overtime [7](9) } \\
\text { c) Shift (including night) [7] (11) }\end{array}$ \\
\hline$\overline{\mathrm{A}}$ & 7) Lack of intellectual and social stimulation [13](24) \\
\hline B & 8) Relocations [12](19) \\
\hline $\mathrm{A}$ & 9) Management of conflict of values [9](14) \\
\hline $\mathrm{C}$ & $\begin{array}{l}\text { 10) Relationships with colleagues inside the detention block [7](18) } \\
\text { a) Conflict related to the management of shift rotation [6] (9) } \\
\text { b) Gossip [4] (6) } \\
\text { c) In-group vs. out-group dynamics [2] (3) }\end{array}$ \\
\hline $\mathrm{C}$ & $\begin{array}{l}\text { 11) Hierarchy [5](13) } \\
\text { a) Lack of gratification and appreciation of one's abilitities [3] (9) } \\
\text { b) The authoritarian attitude of superiors [2] (4) }\end{array}$ \\
\hline $\mathrm{D}$ & $\begin{array}{l}\text { 12) Organizational injustice [5] (9) } \\
\text { a) Mechanisms that regulate internal transfers in the prison [3] (7) } \\
\text { b) Procedures regulating career advancement [2](3) }\end{array}$ \\
\hline F & $\begin{array}{l}\text { 13) Physical structure of the prison building [4](13) } \\
\text { a) Temperatures } 4 \text { (5) } \\
\text { b) Hygiene } 2 \text { (3) } \\
\text { c) Functionality } 1 \text { (3) } \\
\text { d) Aesthetics } 1(2)\end{array}$ \\
\hline
\end{tabular}

${ }^{\dagger}$ A- Work content factors, B- factors related to the type of contract and work organization, C- social factors, D- organizational factors, E- external factors, F- physical environment. ${ }^{\S}$ In parenthesis [] the numbers of interviews including the statements referring at the category of sub-category considered; in parenthesis () the number of statements included in the category.

b) Management of the emotional reactions and aggressive auto/hetero behavior of the prisoners: there are numerous episodes of this type that COs have to face, and some types can occur on a daily basis, "the most stressful aspect of our job is we have to manage people who are here against their will $[\ldots]$ people's emotions in conditions of solitude and imprisonment are amplified as well as their reactions. [26]" The most frequent examples reported during the interviews are emotional crises, refusal of food, care, or to enter the cell. Minor protests and unrest are less frequent but more problematic. The most problematic aspects are fights involving a number of prisoners, threats, and self-harm.

In this category stress is primarily related to fear for one's own safety and the fear of losing control of the situation. 


\footnotetext{
${ }^{6}$ According to ISTAT (http://www.istat.it/it/files/2012/12/I-Dete nuti-nelle-carceri-Italiane-anno2011.pdf), 37\% of inmates in Italian prisons were not born in Italy and, in most cases $(50.4 \%)$, they came from countries of North-Africa.
}

allowed to enter the facility and prisoners are released are perceived as being sources of stress for COs since they have to keep control of a much more complex situation. The COs describe these times as being hectic since this type of situation involves having to maintain a high level of attention while monitoring multiple aspects at the same time: "Obviously if a prisoner is missing from a cell, I am expected to know where he is and why he is missing [...] there are lots of activities, the inmates are not stationary, they move constantly, [...] there are so many open sections, it is not a rigid or closed system, as rigid means that I can only open the cell of one detainee at a time, that is the closed system which is a one to one relationship. However this is an open system, they move around [..] there are civilians among these detainees [...] [8]."

b) "Safeguarding" the life of a prisoner: suicide is frequent in prisons among inmates. COs are responsible for recognizing unusual behavior in a prisoner and for taking direct action to prevent a suicide attempt. This aspect is perceived as being very stressful, especially during the night shift when COs cannot count on their superiors or treatment staff. As a consequence, they may experience feelings of anxiety, psychological tension, and develop a hypervigilant attitude.

3) Negative social image (hierarchically subordinated to $\mathrm{D}$ - external factors). This aspect was mentioned by $26 \mathrm{COs}$ during the interviews. Belonging to the Penitentiary Police Corps is sometimes considered as a true social stigma: "I try not to tell people what I do, it's bad but I am ashamed of it [2]." According to the participants, the negative connotation of the image of COs is mainly due to the inaccurate generalizations that civilians and the media tend to make. The negative stereotypes that the participants mention and fear of being identified with their profession are reported below:

a) The "batterer" who is linked to reported episodes of violence towards detainees by police officers "Do they really believe that we come here to have fun beating the prisoners [..] most of us try to avoid conflict with the detainees [...]. I'm not denying that these things do not happen [..] this type of manipulation is just not right [..] five hundred people are involved who are just trying to do a good job [4]." 
b) The "uneducated" suggesting a low intellectual level of the members of the corps: "we are considered as low-grade people [27]."

c) The "conspirator" because of working in close contact with those who commit crimes ("those who associate with cripples learn how to limp [4]").

4) Health risks (hierarchically subordinated to Ajob-content factor): 24 respondents referred to this aspect as being a source of stress. The negative experiences are substantially due to fear for their physical safety. Two main types of risk are stated:

a) Infections and diseases: being in close and continual contact with the prisoners is considered to be unhealthy especially in certain sections. COs are often afraid of contracting infections or diseases of which detainees can knowingly or unknowingly be carriers, "many of them have diseases [...] it does not happen often, but sometimes colleagues are infected with something they have definitely caught in here [16]."

b) Accident: actions taken for quelling riots or assaults are occasions in which the operator is exposed to risk of injury: "I may have been a little unlucky, however in my opinion the danger of being attacked greatly increases our stress levels. Of course, it is part of our job but risking one's life [...] [12]."

5) Critical events (hierarchically subordinated to Awork content factors): The events experienced by COs that during the interviews they describe as being critical can be divided into two main types:

a) Those in which the CO's health is not at risk as in the case of episodes of self-harm or suicide (attempted or successful): "I still have vivid memories of certain things that I experienced as a new arrival when I was making a round of inspection alone at night with a flashlight and I found someone who had hanged himself on the grating. I' $m$ not saying that I think about it all the time but I often have nightmares and wake up with a start, these things are hard to forget [12]." According to many COs, suicides are traumatic experiences, and they often say that after the initial shock, they sometimes experience a feeling of guilt. Sometimes the thought of what they could have done to prevent the suicide can greatly affect them: "However, the thought that you were not able to save him and what could you have done lingers on [18]."

b) Those that present risks to the physical safety of COs such as riots, assaults, and the threat of being infected by HIV-positive prisoners, "one particular episode upset me enormously, I feel terrible if I think about it even now [7]".

6) Challenging working hours contrasting with social time (hierarchically subordinated to B- factors related to the type of contract and work organization). In order to guarantee 24-hour service, the COs are required to work a cycle of three shifts (including night duty) and they often have to work overtime and give up their days off in order to cover vacant shifts ("there are people who may work all week without having a day off or they might get one after working non-stop for three weeks [21]"). The continual physical fatigue and the constant changes in sleep-wake rhythms are the main complaints.

The unpredictability of working hours and shift coverage on public holidays prevent the COs from dedicating time to hobbies and sports or to their families and friends: "Here, you never know, for example on Monday you can't say "I'm taking my girlfriend to the beach on Sunday" because at the last minute you might be put on duty. Not to mention the holidays, you might be lucky, if not, you will spend Christmas and New Year in here [28]."

7) Lack of intellectual and social stimulation (hierarchically subordinated to A- work content factors). The daily tasks of those employed in the section are described as being monotonous, unrewarding, and in no way able to offer opportunities to those who have expectations of learning and developing skills in the course of their work. In particular, the lack of challenging and/or relevant objectives from a social point of view as well as the impossibility of being involved in team work where one can see the value of one's contribution are aspects that 13 participants perceived as being stressful: "You have the keys in hand for opening and closing the cells, that is all [...] let's just say that the field is narrow, everything soon becomes monotonous [...] you do not feel involved in the job [...] you never learn anything new and or feel that you have achieved any results. [6]"

8) Relocation (hierarchically subordinated to Bfactors related to the type of contract and work organization). In most cases, COs work in correctional facilities far from their homes and consequently temporary or permanent relocation is required. The separation from one's place of origin, the management of long distance relationships with family members, and lone- 
liness where the job is located are the main issues mentioned in relation to stress. In some cases, it is reported as being a distressing experience which one overcomes: "I assure you that being far away from my loved ones was a trauma [...] I can see that the new kids are disoriented when they first arrive just like I was and I feel so sorry for them [12]." Other COs were recently transferred, and were still feeling bewildered at the time of the interview: "I have been here for three months, [... ] I came here alone, I can tell you it's tough [22]."

9) Conflict of values (hierarchically subordinated to A- work content factors). Closing the detainee in the cell, using duress if he refuses, and conducting searches are duties which characterize a CO's job description. Some operators speak of their difficulties in accepting their roles as a "executors of the deprivation of freedom" towards other human beings, "it always has a certain effect on me whenever I think about it [1]." These actions are referred to as being contrary to their own personal values.

Moreover, during the interviews, many situations were described in which the COs experience a conflict, often caused by a lack of organizational resources, between how their job requires them to behave towards the prisoners and the affective response that the situation leads to "from a personal, humanitarian point of view," which would make them act differently: "prisoners live in inhumane conditions on the block I am working in today, even 5 minutes longer in the fresh air would be a great gift for them [...] I'd let them stay outside longer but regulations do not allow it, my heart bleeds when it's time to bring them back inside [5]."

10) Relationships with colleagues inside the detention block (hierarchically subordinated to D- social factors). Each block is a detention facility in its own right with its own organization and staff. According to the COs' responses, in each block there tends to be a well-defined social network which is independent from the rest of prison ("each block is a structure in itself [4]"): once again, the metaphor of the family is used [4 respondents] for describing the network of relationships within the block. The majority of participants spoke positively of their relationships with colleagues. However, a minority of participants described the relationships with their colleagues on the block as being an element of stress. Their reasons for feeling uneasy can be divided into three main categories:

a) Conflict related to the management of shift rotation: "Shifts are the main cause of quarrels $[1,7] . "$ b) Gossip "If you tell a colleague about something or something happened that you may not want people to know about, you can be sure that everyone will know about it the next day which unfortunately is stressful [13]."

c) "In-group vs. out-group" dynamics: "Here there is a very close-knit group, if they don't accept you it is bad: they exclude you, they don't help you [25]."

11) Hierarchy (hierarchically subordinated to Dsocial factors). The superior-subordinate relationships within the Penitentiary Police Corps are part of a pyramid system based on the principles of military organization. None of the participants questions the system and the principles that govern it. However, some participants reported stress-related elements in the relationship with their immediate superiors:

a) Lack of gratification and appreciation of one's abilities: "another issue that derives from having to obey orders is that you are forced to do things that you know are useless and should be done differently but you have to do them, it has happened to me and it made me feel bad [3]."

b) The authoritarian attitude of superiors: "it is great when those in command tell you to do things in a polite way as you're obliged to do them anyway. It bothers me if they don't and makes me feel bad, what is missing is gratification, believe me [24]."

12) Perception of injustice. Two subcategories are related to the topic of the perception of unfairness.

a) Mechanisms that regulate internal relocation in the prison: they are defined as non-transparent and more related to personal preference than to duties and staff: "You need friends at higher level of the union hierarchy if you want to be trasferred where you want [9]."

b) Procedures regulating career advancement: four participants believe that the procedures don't recognize qualifications and work experience reported by the worker: "my boss has an educational level lower than me [...] I think that it is unfair [3]."

13) The physical structure of the prison building (hierarchically subordinated to F- physical environment). The report regarding the physical structure of the workplace is divided into the following categories:

a) Temperatures: "in winter it is very cold, one has to go around in a parka, while temperatures are 
sweltering in summer and there are more episodes of self-harm among the prisoners since they live in overcrowded conditions in the cells. When it's hot the situation becomes critical and greatly affects their mood which is usually pretty bad anyway [3]."

b) Hygiene: "There are serious hygiene issues, there are mice in the blocks [..] [17]."

c) Functionality: the structure is described as not being suitable for housing and ensuring a dignified existence for the inmates and providing the space required by the COs for carrying out their work: "you never know where to hold meetings or conversations [1]."

d) Aesthetics: "It's a really bad environment, dark, sad and dirty [12]."

\section{Discussion}

The aim of this exploratory study was to identify the factors that are responsible for negatively affecting the psychological well-being of the COs employed in an Italian prison.

The results seem to confirm what has already been highlighted in previous studies, namely that COs are at high risk of stress. By observing the categories analyzed, it is possible to see that there is a close correspondence between the risk factors reported in the literature and those mentioned above. However, some interesting differences can also be observed.

The largest macro-category is the work content factors (six categories and a total number of 340 statements). In particular, all 28 interviewees cited as one the most stressful parts of the COs' job the relationship with the inmates (134 statements). The five subcategories highlight the pervasive, complex, and ambivalent nature of this aspect of the COs' work and how it negatively affects their cognitive, physical, and especially emotional well-being. Similar results could also be found in the previous literature $[23,48]$. However, the present study brought to light an interesting aspects little considered until now: for the interviewees, the closeness with the inmates means, most of all, being in contact with their suffering and their desperation caused by their state as detainees and worsened by the inability of the Italian penitentiary system to guarantee conditions of dignity in the detention experience. Moreover, feelings of guilt and powerlessness, due to the impossibility of helping the inmates are also highlighted as part of the COs' stress experience. Further research may investi- gate more deeply this aspect of the contact with inmates in order to understand whether it is an Italian peculiarity, for example exacerbated by the lack of resources in the public penitentiary system. In addition, future studies may be aimed at understanding whether the development of feelings of guilt and powerlessness are affected by the COs' custodial vs. rehabilitative orientation [23].

High saturations were also observed for the following categories: high level of responsibilities related the security and custody of the prisoner, risks to physical health, and critical events. These results are fully constitent with the previous literature that had highlighted the risk potential of these factors on COs' psychological and physical health. Even thought, the present study did not consider the positive side of the job experience, it may be interesting to consider that several studies found a positive effect that the perceived danger has on professional accomplishment [33] and commitment toward the job [3]. Future studies may be addressed at investigating the double effects of the dangerousness of the job among COs and at looking for the link between this aspect and the cultural idientity of this kind of profession [49].

Another element of contrast between the literature and this study concerns the issue of role conflict, that is the contrasting demands related to the job. Although role conflict is widely reported in the literature, none of the participants mentioned this issue during the interviews, while about a third recalled experiences related to the theme of the conflict of values. Unlike the former, the latter concerns the contrast between the demands of the job and one's personal values. A possible explanation for this could be that Italian COs continue to deal almost exclusively with security issues even if the prison system added treatment characteristics to the job description more than two decades ago [51]. Therefore, according to the literature concerning the effect of personal values on security and treatment issues among the COs $[19,52,53]$, it is possible to assume that those who prefer security duties do not suffer any kind of conflict, as their personal orientation and job correspond. On the other hand, those who have a personal orientation toward treatment, tend to experience conflict between what is required by their jobs (tasks generally related to security) and their own personal values (more in sync with treatment objectives). Future studies in the Italian penitentiary context would be addressed toward testing this hypothesis.

The macro-category of the contractual and organizational factors contains two categories: working hours in contrast with social events and relocations. The first cat- 
egory includes aspects which have already been widely reported in the literature, namely that night shifts and working on public holidays and weekends increases stress and reduces the possibility of developing a satisfactory social life. The second category concerns the fact, that according to numerous COs, being relocated negatively effects their well-being, which is an aspect that has been overlooked in the literature, probably because it refers to a peculiarity in the Italian context. In fact, due to socio-economic reasons [33], the Italian Penitentiary Police Corps is composed of a large percentage of people from the southern regions of the country. Therefore, many of them are posted to prison facilities in northern Italy in the course of their careers. Future research could be carried out on identifying the risk and protective factors regarding stress among COs subjected to relocation.

In accordance with the literature concerning social factors, two categories were observed which describe elements of stress related to relationships between COs and their peers and superiors. A relatively small number of participants reported these issues and in particular only five out of 28 COs affirmed to have had problems with their superiors. Considering that the only study carried out on this subject concerning the Italian context showed that relationships with superiors was one of the main causes of stress [33], it is reasonable to assume this aspect was underreported in this study. Probably the fact that the interviews were held inside the workplace and that a block superintendent acted as an intermediary between the researcher and the participants created a climate in which the participants avoided speaking about their relationships with superiors.

Only one category emerged concerning organizational variables: procedural justice with particular reference to mechanisms of career advancement. Only five respondents referred to this aspect.

The absence of other aspects described in the literature such as, integration, distributive justice, or communication reported in detail in studies carried out by Lambert and colleagues [38-41], could be due to the fact that these studies focus on samples of workers from both treatment and security departments. The former group, not involved in the present study, is probably more likely to experience stress due to organizational factors, considering that at the organizational level, security issues in prison facilities often take precedence over treatment issues [54].

Concerning the external factors, in this study, the negative social image was an important source of stress according to 26 out of 28 participants. These results seem to indicate that the perception of belonging to a denigrated profession represents a key element for understanding the discomfort of this professional category. This risk factor is particularly relevant because it tends to go far beyond the boundaries of work-time and workspace and results in affecting key elements of the personal sphere, such as personal identity and social relationships.

Finally, the category regarding the physical structure of the prison refers to a unique emerging theme (at the first-order level) in the present study. It highlights an important issue concerning the conditions of the Italian penitentiary system and confirms the data reported by the national agencies $[55,56]$ : the facilities are old, rundown, and unable to hold the number of inmates imprisoned in terms of hygiene and dignity. According to the results of this study, this aspect negatively affects not only prisoners but also COs. Moreover, the findings seems to suggest that the relationship between COs and inmates is significantly affected by the inadequacy of the facilities and the lack of resources. Indeed, according to the COs' perceptions, as the inmates' living conditions become more inadequate, the COs' work conditions become more critical. Indeed, most of the problems indentified in the subcategories in "highdemanding contact to the prisoners" can be partially explained by inadequacy of the facilities and the lack of resources.

\section{Implications for practice}

A reason for the difficulty in managing relationships with inmates, an aspect that the COs indicated as being particularly stressful, can also be identified in the lack of investment in terms of training for developing relational skills. In fact in Italy, the majority of training is spent on security issues [51]. Training aimed at developing relational skills and increasing awareness concerning the emotional implications of their job could help COs in the management of relational dynamics, thus reducing feelings of stress and dissatisfaction.

Moreover, training aimed at developing knowledge concerning ethnic and cultural aspects rather than the psycho-emotional dimension in relation to the experience of imprisonment could provide COs with more tools for understanding and managing the reactions of the prisoner more adequately.

Finally, in line with the results of other studies, Italian COs are highly exposed to the risk of being involved in critical events. About this aspect, it is possible to agree 
with Prati and Boldrin [33] when they suggest that, besides training aimed at developing the skills required for managing these events, COs should be offered psychological counseling in relation to the psychological consequences that may arise following these events.

\section{Strengths and limitations}

The main strength of this study lies in the qualitative nature of the research design, which has seldom been used in literature in reference to prisons up to now. It has enabled an analyses of the wide-range of the experiences and perceptions of the participants, as well as the meaning that they themselves attach to their work experience. The mixed (deductive and inductive) approach also minimized the risk of imposing interpretive categories of the phenomenon of the COs' experience of stress a priori, yet it has helped to understand some new aspects. Interesting results and suggestions have emerged from this study which may be helpful for identifying specific research subjects for future studies, especially if conducted in the Italian context.

The study has some limitations. Firstly, it is essential to consider the "local" nature of the study. The limitation of including COs employed in a single correctional facility does not allow for generalization. Future studies should extend their scope to include prisons located in different geographic areas.

A second aspect concerns the mode of recruitment of the participants carried out by a person in charge of the prison and to a large extent beyond the control of the researcher. Therefore, the data collected may be biased and beyond the control of those who carried out the research.

A third aspect concerns the way in which the data were analyzed. The researcher chose to indicate the number of the statements attributed to each category as well as the number of the interviewees that mentioned a specific theme as a source of stress. This is because the researcher thinks that this work of "quantification" could give added value to the present research by enriching the picture. For example, it helps to give an idea about how much time people spend talking about the specific themes. Further, thanks to this, it becomes clear how wide the base of data is on which the categories were built. However, since the research adopted a mixed approach, the quantification should not be considered fully appropriate. Indeed, in some interviews, some themes emerged spontaneously, whereas in other cases an explicit question was asked. For these reason, this information should be handled with caution and used only to address the interpretation of the results from an "impressionistic" point of view.

Finally, this study focused only on the negative aspects of the work of the COs and did not take the positive aspects into account. Future studies could focus on these aspects in order to understand which factors have a positive effect and how, and to what extent, they mitigate stress or promote well-being for this professional category of workers.

\section{Acknowledgments}

I am grateful to Professor Daniela Converso (Department of Psychology, University of Turin) for her supervision and support during all phases of the research. A special thanks to Salvatore Canní and Silvia Viberti for their help during the data collection of the present research. Finally, I would like to thank the correctional officers that agreed to take part at the research.

\section{References}

[1] Morgan RD, Van Haveren RA, Pearson, CA. Correctional Officer Burnout Further Analyses. Crim Justice Behav 2002;29(2):144-60.

[2] Griffin ML, Hogan NL, Lambert EG. Doing "People Work" in the Prison Setting An Examination of the Job Characteristics Model and Correctional Staff Burnout. Crim Justice Behav. 2012;39(9):1131-47.

[3] Lambert EG, Hogan NL, Dial KC, Jiang S, Khondaker MI. Is the job burning me out? An exploratory test of the job characteristics model on the emotional burnout of prison staff. Prison J. 2012; 92(1):3-23.

[4] Paoline EA, Lambert EG. Exploring potential consequences of job involvement among jail staff. Crim Justice Policy Rev 2012;23(2):231-53.

[5] Roy S, Avdija A. The effect of prison security level on job satisfaction and job burnout among prison staff in the USA: An assessment. Int J Crim Justice Sci 2012;7(2):524-38.

[6] Hogan NL, Lambert EG, Griffin ML. Loyalty, love, and investments the impact of job outcomes on the organizational commitment of correctional staff. Crim Justice Behav 2013;40(4):355-75.

[7] Lambert EG, Hogan NL, Cheeseman K, Barton-Bellessa SM. The relationship between job stressors and job involvement among correctional staff: A test of the job strain model. Howard J Crim Justice 2013;52(1):19-38.

[8] Lambert EG, Kelley T, Hogan NL. The Association of Occupational Stressors with Different Forms of Organizational Commitment Among Correctional Staff. Am J Crim Justice 2013;38(3):480-501.

[9] Lambert EG, Kelley T, Hogan NL (2013). Hanging on too long: The relationship between different forms of organizational commitment and emotional burnout among correctional staff. Am J Crim Justice 2013;38(1):51-66.
962 
[10] Lambert EG, Griffin ML, Hogan NL, Kelley T. The Ties That Bind Organizational Commitment and Its Effect on Correctional Orientation, Absenteeism, and Turnover Intent. Prison J 2015;95(1):135-56.

[11] Wright L, Borrill J, Teers R, Cassidy T. The mental health consequences of dealing with self-inflicted death in custody. Couns Psychol Q 2006;19(2):165-80.

[12] Ghaddar A, Ronda E, Nolasco A. Work ability, psychosocial hazards and work experience in prison environments. Occup Med 2011;61(7):501-8.

[13] Morse T, Dussetschleger J, Warren N, Cherniack M. Talking About Health: Correction Employees' Assessments of Obstacles to Healthy Living. J Occup Environ Med 2011;53(9):1037-45.

[14] Obidoa C, Reeves D, Warren N, Reisine S, Cherniack, M. Depression and work family conflict among corrections officers. J Occup Environ Med 2011;53(11):1294-301.

[15] Stack SJ, Tsoudis O. Suicide risk among correctional officers: A logistic regression analysis. Arch Suicide Res 1997;3(3):183-6.

[16] Schaufeli WB, Peeters M. Job Stress and Burn out among correctional officers: A literature Review. Int J Stress Manag 2000;7(1):19-48.

[17] Keinan G, Malach-Pines A. Stress and Burnout Among Prison Personnel Sources, Outcomes, and Intervention Strategies. Crim Justice Behav 2007;34(3):380-98.

[18] Finney C, Stergiopoulos E, Hensel J, Bonato S, Dewa, CS. Organizational stressors associated with job stress and burnout in correctional officers: A systematic review. BMC Public Health 2013;13(1):82.

[19] Allard T, Wortley RK, Stewart AL. Role conflict in community corrections. Psychol Crime Law 2003;9(3):279-89.

[20] Pollock JM, Hogan NL, Lambert EG, Ross JI, Sundt JL. A Utopian Prison: Contradiction in Terms? J Contemp Crim Justice 2012; 28:60-76.

[21] Garland B, Hogan NL, Lambert EG. Antecedents of Role Stress Among Correctional Staff: A Replication and Expansion. Crim Justice Policy Rev 2013;25(5):527-50.

[22] Lambert EG, Hogan N, Barton SM, Jiang S, Baker DN. The impact of punishment and rehabilitation views on organizational commitment among correctional staff: A preliminary study. Am J Crim Justice 2008;33(1):85-98.

[23] Misis M, Kim B, Cheeseman K, Hogan NL, Lambert EG. The impact of correctional officer perceptions of inmates on job stress. Sage Open 2013;3(2):2158244013489695.

[24] Hartley DJ, Davila MA, Marquart JW, Mullings JL. Fear is a disease: The impact of fear and exposure to infectious disease on correctional officer job stress and satisfaction. Am J Crim Justice 2013;38(2):323-40.

[25] Gordon JA, Proulx B, Grant PH. Trepidation among the "keepers": Gendered Perceptions of Fear and Risk of Victimization among Corrections Officers. Am J Crim Justice 2013;38(2):245-65.

[26] Boudoukha AH, Hautekeete M, Abdelaoui S, Groux W, Garay D. Burnout et victimisations: Effets des agressions des personnes détenues envers les personnels de surveillance. Encephale 2011;37(4):284-92.

[27] Whitehead JT. Burnout in probation and corrections. New York: Praeger; 1989.

[28] Carli R, Lo Cascio E. Un modello di analisi della violenza istituzionale: l'istituzione detentiva. In: Devoto A., editor. L'uomo e la violenza, Milano: Franco Angeli; 1978, pp. 31-54.
[29] Dowden C, Tellier C. Predicting work-related stress in correctional officers: A meta-analysis. J Crim Justice 2004;32: 31-47.

[30] Castle TL, Martin JS. Occupational hazard: Predictors of stress among jail correctional officers. Am J Crim Justice 2006;31(1):65-80.

[31] Pisarski A, Brook C, Bohle P, Gallois C, Watson B, Winch $\mathrm{S}$. Extending a model of shift-work tolerance. Chronobiol Int 2006;23(6):1363-77.

[32] Lambert EG, Minor KI, Wells JB, Hogan NL. Leave Your Job at Work The Possible Antecedents of Work-Family Conflict Among Correctional Staff. Prison J 2015;95(1):114-34.

[33] Prati G, Boldrin S. Fattori di stress e benessere organizzativo negli operatori di polizia penitenziaria. G Ital Med Lav Erg 2011;33(3):B33-B39.

[34] Lambert EG, Hogan NL, Barton-Bellessa SM, Jiang S. Examining the relationship between supervisor and management trust and job burnout among correctional staff. Crim Justice Behav 2012;39(7):938-57.

[35] Brewer G, Whiteside E. Workplace bullying and stress within the prison service. Journal of Aggression. Conflict and Peace Research 2012;4(2):76-85.

[36] Zapf D, Escartín J, Einarsen S, Hoel H, Vartia, M. Empirical findings on prevalence and risk groups of bullying in the workplace. In Einarsen S, Hoel H, Zapf D, Cooper C, editors. Bullying and harassment in the workplace. Developments in theory, research and practice, Second Edition. New York: Taylor \& Francis, 2011, pp. 75-105.

[37] Morin KM. The late-modern American jail: Epistemologies of space and violence. The Geographic J 2015; 10.1111/geoj.12121.

[38] Lambert EG, Hogan N L, Barton S, Clarke, A. The impact of instrumental communication and integration on correctional staff. Justice Professional 2002;15(2):181-93.

[39] Lambert EG, Hogan NL, Allen RI (2006). Correlates of correctional officer job stress: The impact of organizational structure. Am J Crim Justice 2006;30(2):227-46.

[40] Lambert EG, Hogan NL, Griffin ML. The impact of distributive and procedural justice on correctional staff job stress, job satisfaction, and organizational commitment. J Crim Justice 2007;35(6):644-56.

[41] Lambert EG, Hogan NL. The Association of Distributive and Procedural Justice With Organizational Citizenship Behavior. Prison J 2013;93(3):313-34.

[42] Rousseau V, Salek S, Aubé C, Morin EM. Distributive justice, procedural justice, and psychological distress: The moderating effect of coworker support and work autonomy. J Occup Health Psychol 2009;14(3):305-17.

[43] Crow MS, Lee CB, Joo JJ. Organizational justice and organizational commitment among South Korean police officers: An investigation of job satisfaction as a mediator. Policing 2012;35(2):402-23.

[44] Petitta L, Rinaldi AC, Manno S. Job burnout ed efficacia personale negli operatori penitenziari. Risorsa Uomo 2009; $15: 166-82$

[45] King N. Template Analysis. In Symon G, Cassel C, editors. Qualitative methods and analysis in organizational research. London: Sage; 1998, pp. 118-34.

[46] King N. Using templates in a thematic analysis of text. In Symon G, Cassel C, editors. Essential guide to qualitative methods in organizational research. London: Sage; 1998, pp. 256-70. 
[47] King N. Doing Template Analysis. In Symon G, Cassel C, editors. Qualitative Organizational Research: Core Methods and Current Challenges. London: Sage; 2012, pp. 426-50.

[48] Ferdik FV, Smith HP, Applegate B. The role of emotional dissonance and job desirability in predicting correctional officer turnover intentions. Crim Justice Stud 2014;27(4):323-43.

[49] Redmond SA, Wilcox SL, Campbell S, Kim A, Finney K, Barr K, Hassan AM. A brief introduction to the military workplace culture. Work 2015;50(1):9-20.

[50] Cox T, Griffiths A. The nature and measurement of work stress: Theory and practice. The evaluation of human work: A practical ergonomics methodology. London: Taylor \& Francis; 1995.

[51] Pajardi D. Oltre Sorvegliare e Punire. Esperienze e riflessioni di operatori su trattamento e cura in carcere. Milano: Giuffrè Editore; 2008
[52] Lambert EG, Hogan N, Barton SM, Jiang S, Baker DN. The impact of punishment and rehabilitation views on organizational commitment among correctional staff: A preliminary study. Am J Crim Justice 2008;33(1):85-98.

[53] Lambert, EG, Hogan, NL. Exploring the predictors of treatment views of private correctional staff: A test of an integrated work model. J Offender Rehabil 2009;48(6):504-28.

[54] Armstrong G, Griffin M. Does the job matter? Comparing correlates of stress among treatment and correctional staff in prisons. J Crim Justice 2004;32:577-92.

[55] De Vito CG. Camosci e Girachiavi. Storia del carcere in Italia. Bari: La Terza; 2009.

[56] Associazione Antigone. L'Europa ci guarda: Decimo rapporto sulle condizioni di detenzione in Italia. Torino: Gruppo Abele Edizioni; 2013. 